Слід наголосити, що односторонній симптом «барабанних паличок» надзвичайно рідкісний прояв артериїту Такаясу [3, с. 52]. Отже, виявлення даного процесу лише 3 однієї сторони повинно викликати клінічну настороженість 3 підозрою на АТ та негайною діагностикою 3 початком лікування.

\title{
Література:
}

1. Russo RAG, Katsicas MM. Takayasu arteritis. Front Pediatr. 2018;6:265.

2. Hellmich B, et al. 2018 update of the EULAR recommendations for the management of large vessel vasculitis. Ann Rheum Dis. 2020;79(1):19-30.

3. Spicknall KE, Zirwas MJ, English JC III. Clubbing: an update on diagnosis, differential diagnosis, pathophysiology, and clinical relevance. J Am Acad Dermatol. 2005;52(6):1020-8.

DOI https://doi.org/10.30525/978-9934-26-075-9-21

\section{ВПЛИВ ФЕНОМЕНУ ЗВИВИСТОСТІ ПУПКОВОГО КАНАТИКА НА ПАТОЛОГІЮ ПЛОДА}

\author{
Пилипчук I. C. \\ кандидат медичних наук, \\ асистент кафедри акушерства та гінекологї \\ Львівський начіональний медичний університет \\ імені Данила Галищького \\ Флуд В. В. \\ кандидат медичних наук, \\ асистент кафедри акушерства та гінекології \\ Львівський начіональний медичний університет \\ імені Данила Галицького \\ м. Львів, Украӥна
}

Пупковий канатик - це невід'ємна частина посліду, поєднує плід, який розвивається 3 плацентою для підтримки його живильними речовинами, елімінації продуктів життєдіяльності, обміну газів. Пупковий канатик людини містить дві артерії, які несуть деоксигеновану кров від плода до плаценти, і велику вену пуповини, через яку до плода надходить оксигенована кров. Між двома артеріями розташовуються 
анастомози Хиртля. Для здорового розвитку плода $\epsilon$ важливим відсутність патології пупкового канатика та відсутність порушення току крові [2].

Особливу увагу викликає феномен звивистості або спіралевидності пуповини. Перші спостереження спіралевидності пуповини датуються 1521 роком. Значна перша робота, яка присвячена феномену звивистості пуповини, належить H.W. Edmonds (1954). Звичайно, що він був не першим, що зауважив звивистість пуповини. Він цитує Беренгаріуса (1521) і Фабріціуса (1600). В англомовній літературі для даного феномена застосовують терміни helix, twist, spiral, spin. Ця характеристика пуповини довший час не була об'єктом уваги науковців. Lacro R.V. et al. (1987) провів фундаментальне дослідження з цього питання. В 1993-94 роках були опубліковані дві статті Strong T.H. et al., присвячені ультразвуковій діагностиці так званого неспірального розташування судин пуповини. I вони роблять висновки про те, що неспіральне розташування судин являється маркером можливих перинатальних ускладнень. За останні десятиліття з'явились десятки робіт, присвячені цій проблемі.

Формування витків починається з 8-9 тижня вагітності, коли співвідношення об'єму навколоплодової рідини максимальне по відношенню до розмірів плода. Роль та функціональне значення скручування пуповини (спіну) остаточно не вивчене [3].

Вектор закручування судин по довжині пуповини [4]:

- лівий спін (норма);

- правий спін;

- змішаний спін;

- відсутність спіну

За різними даними літератури, частота лівого спіну (проти годинникової стрілки) зустрічається частіше - 79-83\%, ніж правого 13-15\%, двоспрямованість-4-5\%, відсутність спіну - 4-5\%.

Припускають, що скручування пуповини $є$ результатом рухової активності плода, а відсутність спіну може свідчити про знижену активність або патологію з боку центральної нервової системи. Не виключено, що звивистість пуповини пов'язана із гемодинамічними факторами, a саме із різницею тиску в артеріях пуповини при різному їхньому діаметрі. Цим пояснюється гіперзвивистість пуповини у близнюкареципієнта за наявності фето-фетального синдрому.

T.H. Strong у 1994 році запропонував індекс спіралізації (ICC) пуповини як співвідношення між кількістю витків та іï довжиною i визначено за середнє значення (медіану) 1 виток на 5 см або 0,2 $\pm 0,1$ витка на 1 см. Більш пізніми дослідженнями визначено нормальне 
розподілення ICC: 5 процентилів - 0,06; 50 процентилів - 0,18; 90 процентилів - 0,37 [1].

Індекс звивистості:

- слабкий спін;

- нормальний спін $(0,21+0,07$ (стандартне відхилення)/1 см);

- виражений спін;

- перекрут.

Для нормальної пуповини, при доношеній вагітності нормальної довжини кількість витків рівна 11-12. Гіперзвивистість та гіпозвивистість асоційована із несприятливими перинатальними наслідками [6]. Гіпозвивистість часто асоціюється із трисомією, передчасними пологами, антенатальною загибеллю плода, зростанням інтранатальних ускладнень та оперативного розродження у зв'язку із дистресом плода, низькою оцінкою новонародженого за шкалою Апгар (нижче 7 балів на 5 хв), оболонковим прикріпленням пуповини, синдромом єдиної артерії пуповини. Гіперзвивистість пов'язана з генетичною патологією (часто трисомією), синдромом затримки розвитку плода, асфіксією, патологією судин пуповини, з високою частотою передчасних пологів. Максимальна кількість витків, що знайдені в пуповині (380) описав Shauta F. (1881). Звичайно, що в цьому випадку мова була про посмертні зміни (перекрут). Але не зрозуміло, чи перекрут був причиною чи наслідком загибелі плода; більшість авторів схиляються до другого варіанту (Edmonds H.W., 1954). Аномальна звивистість пупкового канатика $€$ також основою тромбозу судин хоріальної пластинки, вени пуповини, стенозу пуповини [5].

Тому, на сьогодні ICC розглядають як один 3 найбільш значущих параметрів пуповини, що належить до чинників високого перинатального ризику. Такі фактори ризику, як цукровий діабет, прееклампсія підвищують вірогідність аномальної звивистості пупкового канатика (гіперзвивистість, відсутність витків). На жаль, дотепер інформативність антенатальної діагностики та оцінювання ICC за допомогою УЗД оцінюється як невисока - до 40\% діагностичних випадків. Дана патологія пуповини потребує подальшого вивчення та досліджень. С підстави сподіватись, що своєчасне антенатальне виявлення аномальних варіантів звивистості пуповини та вдосконалення спеціальних навиків виявлення сприятиме вибору оптимальної тактики ведення вагітності та пологів, а також зниженню перинатальної смертності.

\section{Література:}

1. Назаренко Л.Г. Актуальні уявлення щодо ролі патології пуповини у перинатальній медицині (клінічна лекція). Здоровье женщины. 2018; № 10 (136). С. 10-14. 
2. Пилипчук I.C., Пилипчук C.I. Патологія пуповини: сучасні погляди на проблему: колект. монографія. Люблін: Люблінський медичний університет, 2021. $436 \mathrm{c.}$

3. Чагаев Ч.Г. Патология пуповины / под ред. В.Е. Радзинского. Москва, 2011.95 с.

4. Экстраэмбриональные и околоплодные структуры при нормальной и осложненной беременности / за ред. В.Е. Радзинского, А.П. Милованова. Москва, 2004. 393 с.

5. Collins J.H., Collins C.L., Collins C.C. Umbilical cord accidents, 2004. $72 \mathrm{p}$.

6. Machin G.A. Abnormal umbilical cord coiling is associated with adverse perinatal outcomes. Pediatr. Dev Pathol. 2000; №3 (5). P. 462-471.

DOI https://doi.org/10.30525/978-9934-26-075-9-22

\title{
MORPHOLOGICAL CHANGES OF RATS LEFT VENTRICLE MYOCARDIUM UNDER THE INFLUENCE OF INFUSION SOLUTIONS
}

\author{
Radoha R. V. \\ Candidate of Medical Sciences, \\ Associate Professor at the Department of Human Anatomy \\ National Pirogov Memorial Medical University \\ Fomina L. V. \\ $M D$, Doctor of Medical Sciences, \\ Professor at the Department of Human Anatomy \\ National Pirogov Memorial Medical University \\ Guminskiy Yu. I. \\ $M D$, Doctor of Medical Sciences, \\ Professor at the Department of Human Anatomy \\ National Pirogov Memorial Medical University \\ Vinnytsya, Ukraine
}

Topicality: Burns are thermal injuries that affect humanity since antient times. Scientists all over the world are searching for an appropriate and effective methods of treatment [1, p. 328]. Data from hospitalized burn patients worldwide reveal from $3 \%$ to $10 \%$. The average proportion of the 